\title{
Partnering Contracts and the inefficient Nash Equilibrium
}

\author{
Tvarnø, Christina D.; Schleimann, Henriette
}

Document Version

Final published version

DOI:

$10.2139 /$ ssrn.3356622

Publication date:

2019

License

CC BY-NC-ND

Citation for published version (APA):

Tvarnø, C. D., \& Schleimann, H. (2019). Partnering Contracts and the inefficient Nash Equilibrium. Copenhagen Business School [wp]. CBS LAW Research Paper No. 19-13 https://doi.org/10.2139/ssrn.3356622

Link to publication in CBS Research Portal

\section{General rights}

Copyright and moral rights for the publications made accessible in the public portal are retained by the authors and/or other copyright owners and it is a condition of accessing publications that users recognise and abide by the legal requirements associated with these rights.

\section{Take down policy}

If you believe that this document breaches copyright please contact us (research.lib@cbs.dk) providing details, and we will remove access to the work immediately and investigate your claim. 

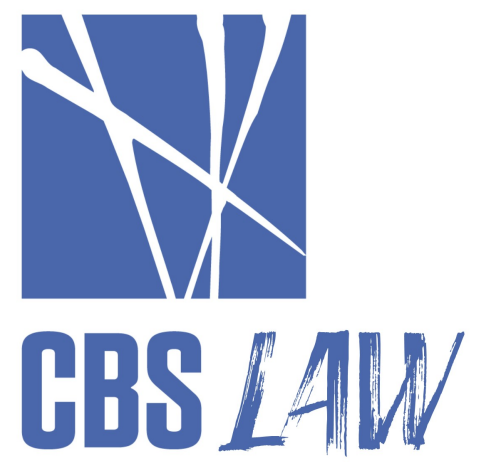

COPENHAGEN

BUSINESS SCHOOL

HANDELSHOJSKOLEN

Copenhagen Business School Law Research Paper Series No. 19-13

Partnering Contracts and the inefficient Nash Equilibrium

Christina D. Tvarnø

Henriette Schleimann 


\title{
Partnering Contracts and the inefficient Nash Equilibrium
}

\author{
SSRN - Working paper
}

By

Christina D. Tvarnø* \& Henriette Schleimann

\begin{abstract}
This paper discusses partnering contracts in Denmark and Great Britain, analyses the legal content and applies game theory and the Prisoners' Dilemma game on some of the legal clauses and objectives. The paper defines partnering contracts as alternative social contracts relevant when forming a strategic alliance or another long-term relationship with a certain degree of specificity and frequency. The paper focuses on partnering in the construction industry and compares the clauses in both Danish and British partnering contracts. Based on the analysis, the paper sets up a scientific definition regarding the aim of partnering contracts and shows that economic theory can explain the legal clauses in the partnering contract, and the partnering contract can solve inefficiency in the Nash equilibrium in the Prisoners' Dilemma game. The partnering contract makes it possible to obtain the benefit from joint utility and the paper proposes some legal improvements in this regard.
\end{abstract}

Key words: Partnering, game theory, contract law, joint utility, Nash equilibrium.

*Christina D. Tvarnø is professor at CBS LAW, Copenhagen Business School.

* Henriette Schleimann is phd fellow at CBS LAW, Copenhagen Business School. 


\section{Introduction}

This paper discusses and analyses the purpose of a partnering contract, and some of the specific characteristics in a partnering contract and explain the partnering contract from a game theoretical perspective. The paper compares joint utility in the partnering contract versus self-optimisation in the traditional contract. The contracts analysed in this paper are partnering contracts in the construction industry in Denmark and in Great Britain. Game theory is used to explain the output of contract negotiations and explain how to behave in order to obtain joint utility in a contractual relationship.

\subsection{Concept and data}

The first important definition of a partnering contract is that it is an alternative to a traditional contract. The partnering contract is not here to replace the traditional contract. Partnering contracts are useful and even an economic improvement if the economic transaction concerns for example a strategic alliance or another type of transaction with a close relationship among the parties. ${ }^{1}$ If the transaction and the specificity and frequency call for a hybrid, a partnering contract could be a relevant legal tool, if the parties are interested in prioritising positive elements and relational norms to improve the long-term transaction. The British Partnering contract, the PPC 2000 discussed below, include a legally defined strategic alliance. ${ }^{2}$ The second important definition of the partnering contract is that the contract aims at structure and guide the parties away from being separate parties to be partners. ${ }^{3}$

Thus, the partnering contract sets up a binding legal framework aiming to optimise the transaction among the parties as a whole instead of two parties aiming to optimise their own utility. This purpose is analysed below in section 2 .

The paper draws empirical data from contracts used in the Danish and British construction industry. One reason that partnering was established as a concept in the construction industry was due to the extremely high amount of conflicting cost - in Denmark more than 100 million DKK per year. The conflict culture in the construction industry in Denmark takes up many resources and in Denmark an increase in the number of cases at the Arbitration on Construction (Voldgiftsnævnet for Bygge- og Anlægsvirksomhed) on approx. $50 \%$ from 2002 to 2007 has been seen. Data shows that approx. 11 per cent of the cases in

\footnotetext{
${ }^{1}$ Strategic alliances can be explained as a hybrid in a Williamson universe, but it is the purpose of this article to define the strategic alliance. Williamson, Oliver E. (1985). The Economic Institutions of Capitalism. New York: Macmillan.

2 PPC2000, amended 2008, ACA Standard Form of Contract for Project Partnering, Construction Excellence in the build environment, Construction Industry Council, ACA and Towers \& Hamlins LLP, 2008, by Dr. David Mosey, in section 24.1 and 24.2.

${ }^{3}$ Matton van den Berg \& Peter Kamminga, Optimising Contracting for Alliances in Infrastructure Projects, International Construction Law Review, Vol. 23, No. 1, January 2006. See also Tvarnø, Partnering Contracts - A Solution to the Nash equilibrium? In a Contract Law and Game Theory Perspective. Paper presented at Behavioral Analysis Applied to Economics and to Law, 2013.
} 
2007 used a partnering contract and under half a per cent of the cases in the Arbitration on Construction involved partnering contracts. ${ }^{4}$

The partnering concept comes from the US and Great Britain and came to Denmark in the late 1990's. ${ }^{5}$ In the beginning, the partnering contracts were pilot projects. In 2001 and later on in 2005 the Danish construction industry created a partnering paradigm to be used free of charge by the parties in the construction industry. ${ }^{6}$ The Danish partnering paradigm and the British PPC 2000 Partnering Agreed Document ${ }^{7}$ are used as the legal data in this paper.

\section{The partnering contract}

The Danish as well as the British partnering contracts ${ }^{8}$ are based upon binding clauses concerning joint utility, ${ }^{9}$ open books, ${ }^{10}$ collaboration, openness ${ }^{11}$ and establishment of joint management teams and alternative conflict procedures. ${ }^{12}$

Furthermore, the partnering contract focuses on the function of for example the building instead of the demands from the building owner. ${ }^{13}$ This requires that the building owner describes the needs instead of the usual practice in a traditional construction contract setting up a long list of demands by detailing descriptions of the specific content of the building before inviting the constructor to the table.

\footnotetext{
${ }^{4}$ Danish Construction Authority: Erhverv- og Byggestyrelsens rapport af 6. Maj 2008, Partnering og tvister i byggeriet I, www. Plus.net.dk.

${ }^{5}$ James Barlow, Michael Cohen, Ashok Jasphapara and Yvonne Simpson, Towards Positive partnering, revealing the realities in the construction industry.

${ }^{6}$ Danish BYG Partnering Paradigm 2005 - The Danish Construction Industry Association (Dansk Byggeri, Danish Architects Association (Danske Arkitektvirksomheder), Association of Danish Engineers and TEKNIQ (Danske ingeniører og TEKNIQ): BYG - Partnering i praksis, Vejledning i partnering, 2. Udgave, oktober 2005.

7 PPC2000, amended 2008, ACA standard Form of Contract for Project Partnering, Construction Excellence in the build environment, Construction Industry Council, ACA and Towers \& Hamlins LLP, 2008, by Dr. David Mosey.

${ }^{8}$ James Barlow, Michael Cohen, Ashok Jasphapara and Yvonne Simpson, Towards Positive partnering, revealing the realities in the construction industry.

${ }^{9}$ Section 6.2 in BYG partnering paradigm, 2005 og the Danish construction Authority: Erhverv-og Byggestyrelsens Vejledning i partnering, januar 2006, p. 9, and Byggeriets evalueringscenter, State of the Art Report, June 2003 and The Danish Construction Authority: Erhvervs- og Boligstyrelsen, Arbejdspapir om brug af workshops ved partnering, Projekt nye samarbejdsformer, October 2002, p. 5. ${ }^{10}$ Section 6.1 in the Danish BYG partnering paradigm, 2005." Punkt 6.1: Det er projektledelsens målscetning: at gennemføre projektet inden for budgetrammen med en forbedret økonomi set i relation til kendte kontraktformer - at sikre kvalitet for pengene - at sikre projektets parter en sund forretning at sikre, at projektets totaløkonomi tilgodeses (anloegs-, drifts- og vedligeholdelsesomkostninger)."

${ }_{11}$ Section 2.1 in the Danish BYG partnering paradigm, 2005."Punkt 2.1: Partneringprocessen gennemføres $i$ et toet samarbejde baseret på engagement, åbenhed, cerlighed og gensidig respekt."

${ }^{12}$ Section 11 in the Danish BYG partnering paradigm, 2005.

${ }^{13}$ Section 2.2 in the Danish BYG partnering paradigm, 2005, "Parterne har sat sig som mål, at opføre et byggeri, der opfylder bygherrens behov.
} 
Firstly, just by inviting all parties, including the constructor at the table from the beginning of the partnering contract negotiations, a completely different contract and collaboration will arise.

Secondly, the partnering contract should be the framework contract setting up the procedure to continue to negotiate the transaction going along with the design, construction and delivery of the building.

\subsection{The history of Partnering ${ }^{14}$}

In 1998 Sir John Egan finished his report "Rethinking construction"15 and proposed partnering as a new model to enter into construction relationships suggesting that the contract might not be legally binding (to work). Sir John Egan proposed that:

Effective partnering does not rest on contracts. Contractors can add significantly to the cost of a project and often add no value for the client. If the relationship between a constructor and employer is soundly based and the parties recognize their mutual interdependence, then formal contract document should gradually become obsolete. ${ }^{16}$

This idea has now been abandoned. When establishing one of the first partnering Agreed Documents in Great Britain (the PPC 2000), the partnering contract has been legally binding among the parties signing the contract and today most of the partnering concepts in Great Britain are legally binding. ${ }^{17}$ The partnering tradition in Denmark also stands on the idea that the contract is legally binding. In both Denmark and Great Britain, the partnering concept is, today, an acknowledged concept. ${ }^{18}$

As mentioned above, ACA - the British Association of Consultant Architects ${ }^{19}$ developed a Standard Form of Contract for Project Partnering ${ }^{20}$ as a multiple party agreement called PPC 2000 (amended 2008 Project Partnering Contract-2000)

\footnotetext{
${ }^{14}$ See further on the partnering concept and the development hereoff in Tvarnø, To bind or not to bind, It's in the contract: Formalizing Collaboration Through Partnering Contracts in the US, British and Danish Construction Industries, Journal of Strategic Contracting and Negotiation, Vol. 1, No 4, 2015, s. 288-314.

${ }^{15}$ Sir John Egan, Rethinking Construction, Department of the Environment, Transport and the Regions, $16^{\text {th }}$ of July 1998.

${ }^{16}$ Sir John Egan, Rethinking Construction, Department of the Environment, Transport and the Regions, $16^{\text {th }}$ of July 1998.

${ }^{17}$ Jan Middleton, Construction Law, (2000) 11, 7, p. 6, 1. August 2000 and James Barlow et al. Towards positive partnering, 1997, The policy Press, University of Bristol, p. 4.

${ }^{18}$ Michael Conroy Harris, Construction Law, (2006) 17, 8, No 4, $1^{\text {st }}$ of October 2006.

19 ACA has allowed the authors of this paper to analyse and refer to the PPC2000- Project Partnering Contract. It is not allowed to quote from the PPC 2000 contract (which is) why specific quotas are not possible in this paper. Permission to explain and compare with the Danish partnering regime has been granted from the publisher.

${ }^{20}$ PPC2000, amended 2008.
} 
regarding large projects. ${ }^{21}$ The Danish BYG-partnering standard form is similar to the PPC 2000. One significant difference is that (the) PPC 2000 is a complete contractual form compared to the BYG partnering contract, which is linked to the traditional construction agreed documents in Denmark.

The Danish BYG partnering agreement 2005 has 12 clauses and is referring to the construction law in general to fulfil the contract relationship; excluding some clauses which are not compatible with the partnering concept. The PPC 2000 is more than 65 pages long. These include more than 10 pages of individual clause, 34 pages on standard clauses and 5 pages with legal definitions and an appendix list.

\subsection{Defining partnering}

The PPC2000 partnering contract was the first British agreed Document to involve more than two parties. The legally binding 22 partnering contract includes all parts of the construction from design to delivery. ${ }^{23}$ Through the PPC2000 contract, the parties commit themselves to collaborate and to work with the common purpose of the project in sight, ${ }^{24}$ thus the parties cannot work just to optimise their own utility. Furthermore, the parties are obliged to ensure transparency and share all relevant project information, ${ }^{25}$ such as open books and calculations, ${ }^{26}$ to create and fulfil common goals $^{27}$ and needs. ${ }^{28}$ All characteristics comparable to the Danish BYG partnering paradigm (which holds the same clauses and is a multiple party contract).

The purpose of the British partnering contract is to obtain a joint economic benefit through a common goal, defined as follows:

The first approach essentially sees partnering as a tool for improving the performance of the construction process and emphasises the way it helps to create synergy and maximize the effectiveness of each participant's resources... Secondly, partnering has been seen as a management process... to improve the efficiency of large construction projects... as a variant of total quality management... the formation of a project team with a common set of goals. Finally, others have focused on the contractual and relationship implications of partnering, seeing it as a way of putting the handshake back into doing business... ${ }^{29}$

\footnotetext{
${ }^{21}$ Richard Dartnell, Construction Law (2007) 18, 3, p. 23, $1^{\text {st }}$ of April 2007.

${ }^{22}$ David Mosey, Construction Law (2007) 18, 2, $1^{\text {st }}$ of Marts 2007, p. 6.

${ }^{23}$ PPC2000, amended 2008, § 2.3.

${ }^{24}$ PPC2000, amended 2008, § 1.3

25 PPC2000, amended 2008, § 3.1 .

${ }^{26}$ PPC2000, amended 2008, § 10.1(i).

27 PPC2000, amended 2008, § 4.1(i).

${ }^{28}$ PPC2000, amended 2008, § 10.1(ii).

${ }^{29}$ Barlow, Cohen, Jashapara and Simpson, Towards positive partnering, Revealing the realities in the construction industry, the Policy Press, University of Bristol, 2002, p. 6.
} 
There are several definitions in Denmark to be found on partnering. The most important is in the BYG partnering paradigm BYG's called: Partnering i praksis $2005{ }^{30}$ This paradigm is a legally binding ${ }^{31}$ multiple party agreement based on common goals, open books and an on-going negotiation to solve the needs and functions.

The parties undertake to act in accordance with the intentions of this agreement. It is thus an essential precondition for the agreement and for achieving the objectives and intentions arising out of the agreed collaboration, the parties' cooperation based on trust, full transparency and professionalism. ${ }^{31}$

There is full transparency on the economy and all parties share the responsibility to ensure that the economy is kept within the budgetary framework and is committed to contribute to optimizing the economy in order to achieve increased earnings / savings for all parties. ${ }^{32}$

\section{The Danish Construction Authority defines partnering as:}

The concept of "partnering" refers to a form of cooperation in building and construction project that is based on dialogue, trust and transparency and with the early involvement of all parties. The project is carried out under a common objective formulated by joint activities and based on common economic interests. $^{33}$

... the conduct of the parties sought transformed from a contract oriented (focus on sub-optimization and own rights) to be relationship-based (focusing on the overall optimization and collaboration). ${ }^{34}$

The Authority is focusing on the transformation from a self-centred, "contract based" attitude to relation-based, joint optimisation and collaboration.

\footnotetext{
${ }^{30}$ Danish BYG partnering paradigm, 2005.

${ }^{31}$ Aftalens parter forpligter sig til at handle i overensstemmelse med intentionerne i ncervorende aftale. Det er således en afgørende forudscetning for aftalen og for realisering af den målscetning og de intentioner, der udspringer af den aftalte samarbejdsform, at parternes samarbejde bygger på tillid, fuld åbenhed og professionalisme." Section 4, in BYG partnering paradigm, 2005, "Aftalens parter forpligter sig til at handle i overensstemmelse med intentionerne i nærværende aftale.

${ }^{32}$ Der er fuld åbenhed om økonomien, og alle parter er medansvarlige for at sikre, at økonomien holdes indenfor budgetrammen og er forpligtet til at medvirke til at optimere økonomien med henblik på at opnå en øget indtjening/besparelse for alle parter. Section 6.2 in BYG partnering paradigm, 2005.

33 ..., parternes adfcerd søges cendret fra at voere kontraktorienteret (fokusere på suboptimering og egne rettigheder) til at veere relationsbaseret (fokusere på helhedsoptimering og samarbejde)... See Danish Construction Authority, Erhverv- og Byggestyrelsens Vejledning i partnering, januar 2006 and Byggeriets evalueringscenter, State of the art Rapport, June 2003.

${ }^{34}$ Begrebet "partnering" anvendes om en samarbejdsform i et bygge- og anlogss-projekt, der er baseret på dialog, tillid og åbenhed og med tidlig inddragelse af alle parter. Projektet gennemfores under en foelles målscetning formuleret ved falles aktiviteter og baseret på foelles økonomiske interesser. See Danish Construction Authority, Erhvervs- og Boligstyrelsen, Arbejdspapir om brug af workshops ved partnering, Projekt nye samarbejdsformer, October 2002, p. 5.
} 


\subsubsection{The scientific definition of partnering in this paper}

Based upon the above described definitions the partnering in renewal can be defined as the following:

Partnering is a contract type in which all involved parties, from the beginning to the end of the project, obliges themselves to collaborate on solving the needs and functions of the project described by the owner, with a joint utility perspective and by agreeing on common goals. All parties must increase the utility of the transaction, not their own, and allocate the benefits from joint optimisation in an economic and fair share by awarding when fulfilling the positive incentives, acknowledging, that joint optimisation can only be obtained by full information, open books and calculations, trust, dialogue and use these objectives if a conflict arises.

\section{The economics behind the partnering contract}

The partnering contract is a legal setup to promote long term relational commitments among two or more parties, as for example a strategic alliance or a multiple party construction contract. In a partnering contract, the parties must shift from being parties to being partners, a significant tool to maximise the output from a long-term strategic alliance. Sharing information is also a relevant alliance tool together with the relational norms such as trust, collaboration and incentives, and also tools in strategic alliances used to create a competitive advantage. ${ }^{35}$

The joint utility and common goals can be explained by several economic theories, for example the principal agent theory, the Coase Theorem and Game Theory. This paper will use a game theory perspective on the partnering concept regarding the joint utility.

Looking at the game theory argumentation in the Prisoners' Dilemma game, joint utility will create the highest possible output, but the game will still end up in an inefficient Nash equilibrium, due to the fact that the parties will end up self-optimising even though this will end in the worst possible economic output.

The most significant difference between a traditional contract and a partnering contract is the objective concerning joint utility. Both traditional contracts and traditional contract law are based on the idea of self-optimisation. Every party will optimise their own utility. The lawyers will optimise their client's utility and through that their own utility. The client will control the lawyer/negotiator's capability to obtain the highest pay-off regarding oneself and the law behind all types of contracts will support this perspective.

\footnotetext{
35 Matton van den Berg and Peter Kamminga, (2006). Optimising contracting for alliances in infrastructure projects. The International Construction Law Review, 2006, 59-77.
} 
The negotiations of the contract must result in a joint goal benefitting all and removes the opposite interests among the parties. When optimising the project or the transaction, the parties can focus on a common interest instead of their own interest. For example, in a traditional building contract the building owner will demand the lowest price and the contractor will set the highest possible price. By establishing joint optimisation, it is possible to create both cheaper and better buildings in all parties' interest as long as they share the gains.

\subsection{Joint utility}

In a traditional construction contract the contractor is obliged to deliver the asset in due time, place and condition otherwise he/she will be in breach of contract. The building owner will deliver the right payment in the right time and place. Neither of the parties have an incentive to deliver a better solution than (that) agreed upon. Why obtain a higher risk without being paid to do so?

In a partnering contract the parties are obliged to improve the building by working to fulfil the needs instead of specific demands. By collaborating they can create the solutions to the demand by using lower cost and resources. From a game theory perspective, the parties can obtain a higher output by joint utility, but will not in a traditional contract. They will end up in an inefficient Nash equilibrium.

\subsection{The Prisoners' Dilemma}

Game theory can explain how parties in conflict will react when negotiating, making decisions, cooperating or not cooperating and explain the typical strategy (which) the parties will consider. Thus, game theory is a traditional mathematic study of the decisions made by rational parties.

The game used in this paper is the Prisoners' Dilemma - a game explaining the dilemma between self-optimising and joint utility. The Prisoners' Dilemma game also serves to illustrate that contractual parties cannot joint optimise by themselves why binding legal rules are necessary.

The Prisoners' Dilemma game ${ }^{36}$ illustrates the dilemma between choosing selfoptimisation and joint utility. The two individuals choose not to cooperate even though they can both see the common interest in collaborating, thus the game illustrates the difference between individual and collective rationality. Decisions that are rational

\footnotetext{
${ }^{36}$ Rapoport, Prisoners' Dilemma, The New Palgrave, Game Theory, [1998], Maxmillian, p. 100. See also Rapoport \& Chammah, Prisoners' Dilemma, Ann Arbor, University of Michigan Press. MI.
} 
from the individual's perspective are inappropriate when seen with common eyes, even though an outsider can see the rational gains resulting from a common perspective. ${ }^{37}$

Two people ("the prisoners") have been arrested with stolen goods. The prosecutor only has sufficient evidence to get them prosecuted and convicted for possession of stolen goods if one or both of them confess to burglary. If the prosecutor only prosecutes the prisoners for possession of stolen property, it will lead to a lower penalty than conviction for burglaries. ${ }^{38}$

The two prisoners are placed in isolation and cannot talk to each other. Each prisoner is visited by the prosecutor, and is offered the same deal. If one prisoner confesses and also gives evidence against the other prisoner; the first prisoner will go free, while the other prisoner will receive the maximum sentence of four years of imprisonment.

If both prisoners confess, they will each be sentenced to three years of imprisonment for burglary. If neither confesses, then each prisoner will be imprisoned for half a year for possession of stolen goods, because the break-in cannot be proved.

The dilemma and the economic pay-offs from the decision-making are shown in the matrix 1 below.

\section{Matrix 1 - Prisoners' Dilemma game ${ }^{39}$}

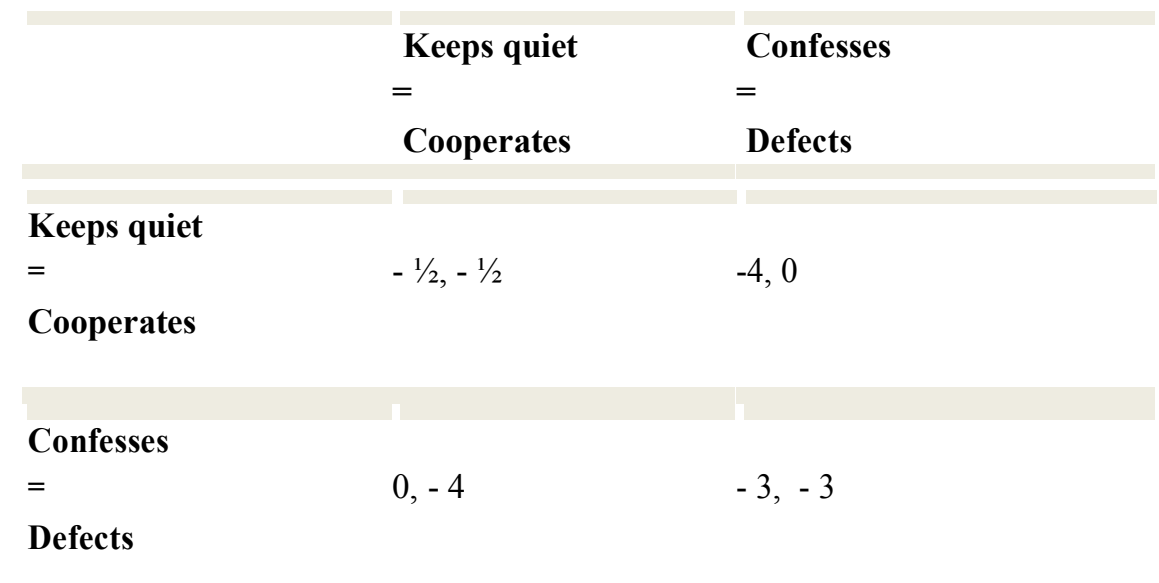

The matrix shows, that "confession" is the dominant strategy because "confession" is the optimal choice for each player regardless of what the other player does. Or stated in economic terms; the only possible Nash equilibrium is to always defect.

\footnotetext{
${ }^{37}$ Rapoport \& Chammah, Prisoners' Dilemma, Ann Arbor, University of Michigan Press. MI.

${ }^{38}$ Anatol Rapoport, Prisoners' Dilemma, The New Palgrave, Game Theory, p. 100.

${ }^{39}$ Cooter, R. B, \& Ulen, T. (2014). Law and economics ( $6^{\text {th }}$ ed., international ed.). Pearson Education Limited, see also Tvarnø, To bind or not to bind, It's in the contract, : Formalizing Collaboration Through Partnering Contracts in the US, British and Danish Construction Industries, Journal of Strategic Contracting and Negotiation, Vol. 1, No. 4, 2015, 288-314, p. 305.
} 
Prisoners 1 and 2 are in the same situation and have the same information. Thus, the game ends by both players spending three years in prison instead of only half a year.

The Prisoners' Dilemma game illustrates that two individuals will not cooperate even when it is obvious that it is in their best interests to do so.

Furthermore, the Prisoners' Dilemma game illustrates that defecting is always chosen in preference to cooperation because a rational, self-interested person evaluates their own options in consideration with the other party's possible choice, knowing that the rational self-interested counterparts do the same - in this scenario the only possible outcome therefore is not to cooperate, but to defect. The risk of being defected by the other person is too high. ${ }^{40}$

When changing the payoffs to positive values the game results in the following. This illustration will be used below in section 3.3.

\section{Matrix 2 - Prisoners' Dilemma game with positive pay-offs ${ }^{41}$}

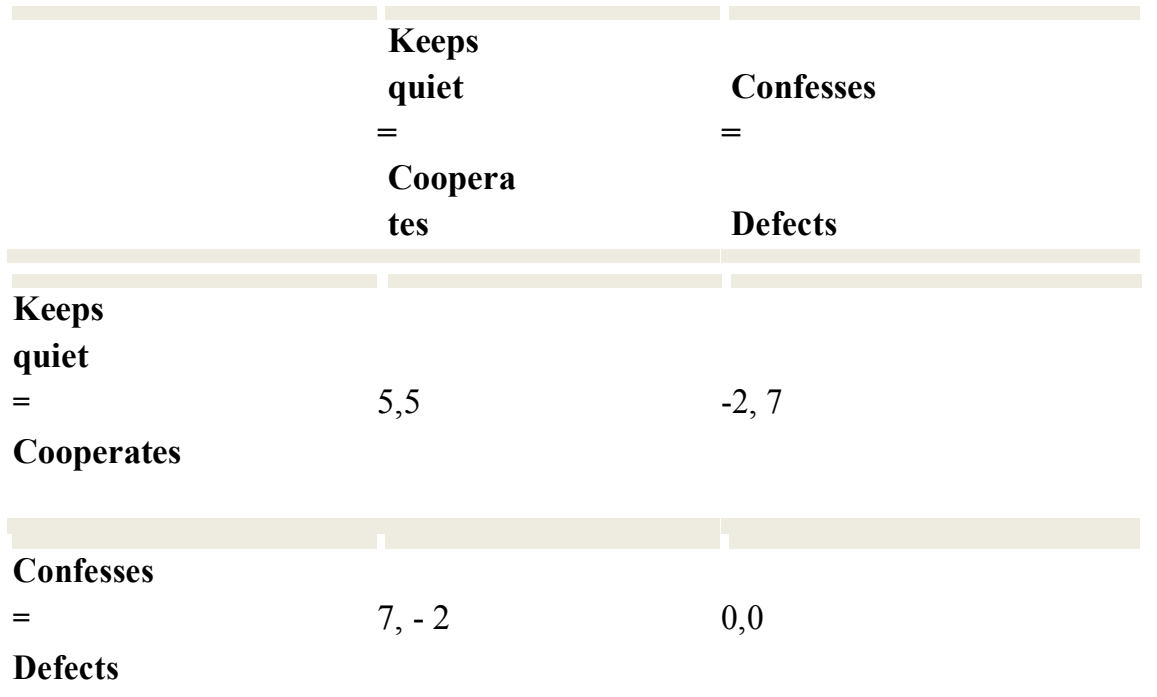

The partnering contract can solve this economic inefficiency by making the parties acknowledge the concept and benefit of joint utility and by creating a legally binding framework making the parties choose the right strategy without being caught in the dilemma between joint and self-optimisation.

\footnotetext{
${ }^{40}$ Tvarnø, To bind or not to bind, It's in the contract, : Formalizing Collaboration Through Partnering Contracts in the US, British and Danish Construction Industries, Journal of Strategic Contracting and Negotiation, Vol. 1, No 4, 2015, 288-314, p. 305.

${ }^{41}$ Dutta, P. (1999). Strategies and games: Theory and practice. MIT Press, p. 210.
} 


\subsection{Long term game theoretical perspective}

A counterargument from a practical perspective could state that real individuals would not act like that; this won't happen in reality. But science has shown that it will happen in the real world. Economic agents in general will choose to selfoptimise instead of seeking joint utility. Only if simultaneous games are played without the parties knowing when the last game will occur, the parties have the incentive to cooperate because they continuously have an opportunity to penalize the other for previous decisions. ${ }^{42}$

According to the classical Prisoners' Dilemma the negotiation will always end in the inefficient Nash equilibrium. However, this paper argues that a partnering contract can solve the inefficient Nash equilibrium, thus move from defect to cooperate. Although the question is how this is possible due to the fact that a game will always end in a Nash equilibrium. The Prisoners' Dilemma game is a one-time game, however if the game where to be played more than once, the game changes. A partnering contract can be characterized as a long term game i.e. repeated game, hence a game changer.

The lack of incentives between the parties in a one-time game results in the Nash equilibrium. Therefore by playing the game several times, the parties are able to build on economic incentives with one another and therefore joint optimize.

In game theory, repeated games are those that play out over and over for a period of time, and therefore are usually represented using the extensive form. ${ }^{43}$ As opposed to one-time games, repeated games introduce a new sequence of incentives, as the possibility of cooperating means that the parties can choose to compromise in order to carry on receiving a payoff over time, being aware that if one party does not comply with the agreed strategy, the opponent may decide not to either. The building owner and contractor offer of cooperation or their threat to defecting the cooperation has to be credible in order for the opponent to uphold their end of the bargain. In this case, the parties have to clarify what the best value creation is for them: the payoff which they gain if they break the pact at any given moment for an exceptional, one-off payoff, or the continued cooperation with lower payoffs which may - or may not - add up to more over a given time. Therefore, each

\footnotetext{
${ }^{42}$ Otherwise, the parties just calculate with a backward induction and continue to betray each other repeatedly. Axelrod, The evolution of cooperation, 1984. See also Rapoport, Tit for tat strategy, in which the strategy is to cooperate from the beginning and then repeat what the counterparty does. See further Rapoport, Prisoners' Dilemma, The New Palgrave, Game Theory, [1998], Maxmillian, p. 100. See also Rapoport \& Chammah, Prisoners' Dilemma, Ann Arbor, University of Michigan Press. MI.

${ }^{43}$ Prajit K. Dutta's Prisoners' Dilemma, Reuer, J. (2009). Strategic Alliances: Theory and

Evidence (Oxford Management Readers). Oxford University Press, p. 214-15.
} 
party (in the following called players) must consider the opponent's possible punishment strategies. $^{44}$

This means that the strategy space is greater than in the classical Prisoners' Dilemma game. Each player will determine its strategies or moves considering all previous moves up until that moment. Also, since each player will consider this information, it will play the game based on the behaviour of the opponent, and must therefore also consider possible changes in the behaviour when making choices. ${ }^{45}$

As an example, suppose that the Prisoners' Dilemma were to be played several times by the same players; would that change the analysis of the game. If the same players play the same game according to the same rules repeatedly, it is a probability that cooperation may arise and that the players have an incentive to establish a reputation, as e.g. trustworthy - which is the case in the Prisoners' Dilemma.

Suppose for example that after the first game is over, and the suspects are either freed or released from jail, a new game option will arise and as the players commit another crime, the game will be played again. However, in this case, initially, the suspects may reason that they should not confess, as their partner will now not confess in the second game. In this type of construction contract it is framed in the initial partnering contract that negotiations on the content of the contract continues in the full duration of the contract period.

Hence negotiations will continue during the contract period, in the second game, both suspects will confess no matter what happened in the first game. However, repetition unlocks the possibility of being rewarded or punished in the future for current behaviour, and game theorists have provided a number of theories to which attempt to explain the obvious intuition that if the game is repeated often enough, the suspects ought to cooperate. ${ }^{46}$

\footnotetext{
${ }^{44}$ Ibid. p. 211-215. See also Wensley, Robin. (2013) Effective management in practice: Analytical insights and critical questions. Sage, p. 97-98. See also Cooter, R. B, \& Ulen, T. (2014). Law and economics ( $6^{\text {th }}$ ed., international ed.). Pearson Education Limited, p. 35.

${ }^{45}$ Cooter, R. B, \& Ulen, T. (2014). Law and economics (6 ${ }^{\text {th }}$ ed., international ed.). Pearson Education Limited, p. 35.

${ }^{46}$ Cooter, R. B, \& Ulen, T. (2014). Law and economics (6th ed., international ed.). Pearson Education Limited, p. 35-36. An important aspect of a repeated game is whether the game will be repeated a fixed number of times or an indefinite number. In order to illustrate the difference, suppose that the Prisoners' Dilemma is to be repeated eight times. Each player's optimal strategy must now be considered across games, not just for one game at a time.

According to game theory, the game unravels so that confession takes place by each player every time the game is played, if it is to be played a fixed number of times. Things could potentially be different if the game is to be repeated an indefinite number of times. In those circumstances, there may be an incentive to cooperation. Robert Axelrod has shown that, in a game like the Prisoners' Dilemma repeated an indefinite number of times, the optimal strategy is tit-for-tat - if the other player cooperated on the last play, you cooperate on this play; if the other player did not cooperate on the last play, you do not on this play. See also Robert Axelrod, The evolution of cooperation, 1984. Cited in Cooter, R.
} 
Although, according to game theorist a game that will be played a fixed number of times, will always end in the inefficient Nash equilibrium, as the players will eventually end up defecting in the last game, knowing that the opponent will defect in the last game, the other party will defect in the second last game and so on, as backwards induction would apply, due to self-optimisation. Although if the game where to be played infinite the parties would eventually end up cooperating. ${ }^{47}$ However, this scenario is not realistic, as every game has an end.

Knowing that the parties would cooperate in infinite games, reciprocity could be the way of solving the inefficient Nash equilibrium, by using the modified Prisoners' Dilemma.

\subsubsection{The modified Prisoners' Dilemma game}

The modified Prisoners' Dilemma is based on the classical Prisoners' Dilemma. However, the modified game has added a third strategy, namely to partly confess, whereas the classical game only have to strategies, namely to confess/not confess. ${ }^{48}$ Matrix 3 below illustrates the modified game between two construction parties, where the third potential strategy is named profit sharing instead. It should be noted, that the game below in matrix 3 also uses positive pay-offs.

Matrix 3 - The modified Prisoners' Dilemma game ${ }^{49}$

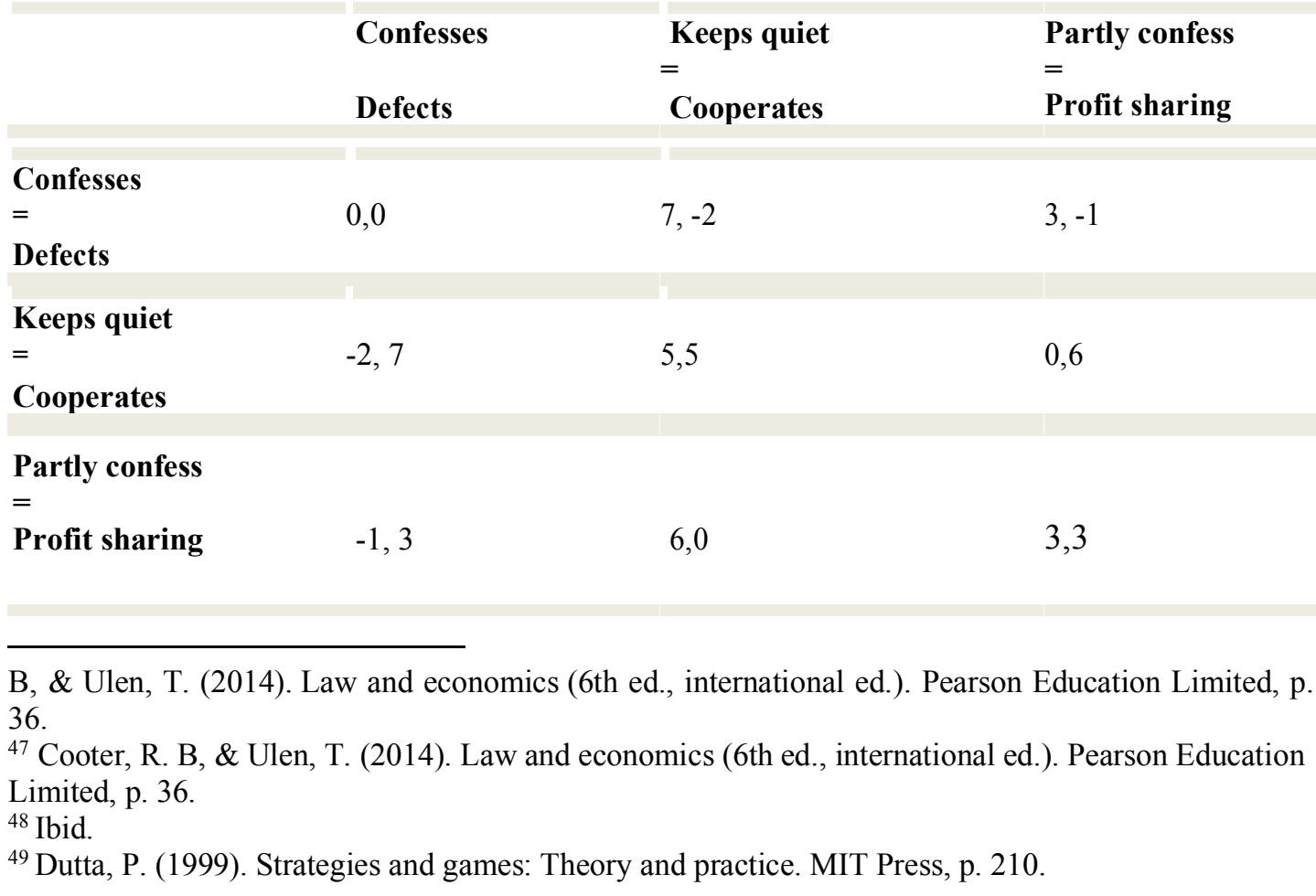


In the modified game, there are two Nash equilibria: $(0,0)$ and $(3,3)$. The modified game is a repeated game and not the usual one-time game. This modified game is based upon a partnering contract between the building owner and the contractor, thus both players have agreed to cooperate throughout the game as set out in the contract. Therefore, within the modified game, the parties have agreed on the outcome which means that if both players choose to cooperate throughout the game, they will share the profit in the last game.

As an example, the parties could play the game seven times. In connection to a repeated fixed game, backwards induction would apply and, therefore, the Nash equilibrium $(0,0)$ would prevail, as defecting is the dominant strategy. However, in the modified game, the parties have agreed to cooperate throughout the entire game. Nevertheless, despite the partnering contract, from an economic perspective, a risk of punishment strategies is still present in the modified game. ${ }^{50}$

As an example if the players played this game seven times, the players can challenge the backward induction, by collaborating with each other and with a potential profit in the end. Thus, if the parties choose to cooperate throughout the game, i.e. choosing the cooperate strategy $(5,5)$, then both of them will get a bonus in the 7 th game, as they would arguably choose the profit sharing strategy $(3,3)$. The example with seven games does not illustrate the continuing contract negotiations in the partnering contract. During a traditional two year contracting period, several more games must be expected, thus the repeated games in this example will not fully describe the practical situation in the construction contract.

The collaborative element must maintain the incentive between the players. The players are rational and they are aiming for the payoff-maximizing strategy. Therefore, in the 7 th game (the contractual end game), the players have agreed on choosing the profit sharing strategy, even though one of the players could potentially punish the other by choosing the weaker defect strategy. If the contractor chooses to defect and the building owner chooses the profit sharing strategy, the contractor would end up with a utility of 3 in that game, where the building owner would end up with 0 , or vice versa. Hence, the players are indifferent in regard to defect in the last game because the payoff of collaboration is equal to the defect strategy i.e. a payoff of 3 .

The risk of punishment strategies are still existing in the partnering contract but in a different legal context compared to the traditional construction contract. If the building owner will punish the contractor for defecting from the agreed strategy it would legally mean that the contractor will not get his part of the joint utility payoff.

\footnotetext{
${ }^{50}$ Ibid.
} 
For instance, if both players choose to cooperate throughout the first 4 games and the contractor chooses to defect in game 5 and the building owner sticks to the cooperate strategy, then the contractor gets the highest pay-off in that game. If this happens the building owner will not trust the contractor in game 6 , where the building owner will defect. The contractor is aware of this, therefore he too will choose to defect and the defecting strategy will become the dominant strategy for the rest of the game. This situation is solved legally by the partnering contract and the incentives payment. If a player defect in a partnering contract the loss is deducted from the incentives clause payment. Thus, the joint utility of both parties will end up being less than if they cooperated through the duration of the contract.

By using a partnering contract, the parties has agreed always to choose the cooperate strategy due to the obligations in the contract - described above in this paper. Hence, the partnering contract could be the solution to the inefficient Nash equilibrium, both because they would end up in the more efficient Nash equilibrium $(3,3)$ in the long term game and because the partnering contract pays them to do so.

\subsection{Full information and open books}

The obligation to have open books and calculations is a significant condition in order to reach the benefit from joint utility. If the parties do not share all relevant information with each other and cannot trust the other parties to reveal their information, selfoptimisation will occur at once. Full information will increase the possibility to cheat and self-optimise. ${ }^{51}$

Positive incentives and collaboration as well as open books and joint utility are obligations to be delivered on the same conditions as delivering the building and payment. Open books and calculations increase the amount of information and by that; information regarding prices, cost, payment, salary, discounts, savings, earnings, etc. ${ }^{52}$ The higher degree of information, the larger is the possibility to achieve joint utility. Information also decreases moral hazard and adverse selection and the risk of hold up. Information is a key element to increase the output of the transaction. The more the legally bound parties are revealing the information regarding the transaction, the closer to joint utility the parties get. ${ }^{53}$

\footnotetext{
${ }^{51}$ Tvarnø, To bind or not to bind, It's in the contract, : Formalizing Collaboration Through Partnering Contracts in the US, British and Danish Construction Industries, Journal of Strategic Contracting and Negotiation, Vol. 1, No 4, 2015, p. 288-314 \& Tvarnø, Partneringaftalens særlige karakteristika, UFR No 45, 8. November 2003, p. 366.

${ }^{52}$ Section 6.2 in BYG partnering paradigm: "Der er fuld åbenhed om økonomien, og alle parter er medansvarlige for at sikre, at økonomien holdes indenfor budgetrammen og er forpligtet til at medvirke til at optimere økonomien med henblik på at opnå en øget indtjening/besparelse for alle parter..."

${ }^{53}$ Steven Shavell, Contracts, The New Palgrave Dictionary of Economics and the Law, p. 433.
} 
Game theory has shown some relevant theoretical information regarding situations in which the economic agent or contract party faces a decision concerning a conflict of interest in which the agent or contract party must choose a strategy. Many similar decisions must be taken every day in contracting, negotiation, employment, pricing, buying, selling, collaborating etc. - situations, where persons must consider how to behave in a certain way or not. ${ }^{54}$

The specific clauses in both the Danish BYG and the British PPC 2000 partnering contracts consist of binding agreements requiring the building owner to describe the needs and functions, and the constructor and design enterprises together with the building owner to collaborate on common goals and to use positive incentives to obtain the goals instead of negative clauses on breach and damages. Furthermore, the clauses obliges the parties to open the books and calculations. The long-term intention in the partnering contract is to stretch out the length of the contract to create the framework for the on-going negotiations to seek the most optimal solutions on the future challenges in the transaction. When building on needs and functions, the design and constructor do not have any specifications to fulfil, but must fulfil a more uncertain goal. A goal negotiated along the way by using the joint utility perspective in the partnering contract. A very different perspective compared to a traditional works contract.

As for traditional contracts the partnering contract is the legal rule among the parties and by that the legal reality even though the framework differs from the contract law doctrine. ${ }^{55}$ It is necessary to bind the parties legally by the partnering contract. If not, the game theory has shown that it is too risky to joint optimise and too tempting to selfoptimise. The risk of being cheated is too big if the parties are not bound by the contract. When using positive incentives and positive pay-offs, the partnering contract demands to share the common benefit from joint utility possible to gain (as shown by the Prisoners' Dilemma game).

Thus, the clauses concerning collaboration, common goals, joint utility, open books, and incentives must be as binding as the obligation to deliver and pay. ${ }^{56}$

\footnotetext{
${ }^{54}$ Cooter, R. B, \& Ulen, T. (2014). Law and economics (6th ed., international ed.). Pearson Education Limited.

${ }^{55}$ Tvarnø, To bind or not to bind. It's in the contract : Formalizing Collaboration Through Partnering Contracts in the US, British and Danish Construction Industries, Journal of Strategic Contracting and Negotiation, Vol. 1, No 4, 2015, p. 288-314 \& Tvarnø, Loyalitetspligt og partneringaftaler, Julebog 2002, ed. Ruth Nielsen, DJØF, p. 149.

${ }^{56}$ Tvarnø, To bind or not to bind. It's in the contract Formalizing Collaboration Through Partnering Contracts in the US, British and Danish Construction Industries, Journal of Strategic Contracting and Negotiation, Vol. 1, No 4, 2015, p. 288-314 \& Tvarnø, Partneringaftalens særlige karakteristika, UFR No 45, 8. november 2003 p. 366.
} 


\section{Solving the inefficient Nash equilibrium through partnering contracts}

The game theory can, as described and analysed above, show how to optimise long term relational and social contracts as for example a strategic alliance. The tool is a legally binding partnering contract; a contract that sets the stage to optimise the transaction. As illustrated by the Prisoners' Dilemma game, the joint utility gives a significant larger pay-off. When entering into a partnering contract, the parties accept a set of rules to govern the process to obtain joint utility. It is a complete package. It is necessary to use all the clauses to prevent the parties from ending in the inefficient Nash equilibrium. Both in the short and long term game theoretical perspective, the partnering contract potentially can solve the inefficient Nash equilibrium, which otherwise normally will be the result of a traditional contract due to the self-optimising behaviour. 